Int. J. Dev. Biol. 53: 1205-1217 (2009)

doi: $10.1387 / \mathrm{ijdb} .072427 \mathrm{jb}$

\title{
A history of Evo-Devo research in Spain
}

\author{
JAUME BAGUÑ $\grave{A}^{*}$ \\ Departament de Genètica, Facultat de Biologia, Universitat de Barcelona, Barcelona, Spain
}

\begin{abstract}
A history of Evolutionary Developmental Biology (Evo-Devo in short) in Spain is presented. From an almost total lack of research and tradition in Embryology, Genetics and Evolution throughout the $19^{\text {th }}$ and well into the $20^{\text {th }}$ century, evolution and development was first bridged in the $1970-80$ s by the structuralist approach of Pere Alberch and by important sidestudies from the Madrid School of Developmental Genetics. A second stage was set in the early 1990s when a few scattered labs start to address problems which arose abroad by major advances in molecular phylogenetics and comparative gene expression patterns in selected animal models. The principal contributions included the nature and molecular features of the first bilaterians and the first chordates, the patterning of the vertebrate brain and limbs, and insect appendages and, on a finer scale, the roles of specific gene and gene families in vertebrate neural crest origin and in the patterning of sensory elements in the Drosophila species. Because a common genetic toolkit exists from sponges to man, current Evo-Devo research is taking a dual approach. On a "macroevolutionary" scale, it asks how and when developmental genes were assembled, at key points in the phylogenetic scale, into interacting functional networks to determine regional and tissue specific identities. On a "microevolutionary" scale, it analyzes how changes in the regulatory and codifying regions of specific genes correlate with specific morphological changes and how they could spread in natural populations. Given the paucity of such studies in current Spanish labs, a call is made to foster them.
\end{abstract}

KEY WORDS: Evo-Devo, molecular phylogeny, gene expression, homology, gene network

\section{The origins of Evo-Devo}

That embryonic development and morphological evolution are deeply linked was first recognized in the last third of the nineteenth century in the aftermath of Darwin's theory of Natural Selection. However, an effective connection between the two had to wait the uncovering of the nature and structure of the hereditary material and to realize that genes control development and, hence, evolution. Although a bit genocentric, the basic rationale behind EvoDevo is often stated as follows: if evolution entails change in morphology, as morphology depends on embryonic development and development depends on developmental genes and gene networks, understanding how developmental genes evolve is the crux to understanding evolution (quoted in Baguñà and GarcíaFernàndez, 2003).

If we accept this tenet, one is left wondering how such connection became established and the forebears of such link. According to Scott F. Gilbert (Gilbert, 2003) while the year 2000 might be considered the birth of Evo-Devo because it witnessed the birth of specific journals devoted to it, 1977 might have been the year of its conception because three works seminal for Evo-Devo were published: Stephen J. Gould's book "Ontogeny and Phylogeny", François Jacob's paper "Evolution by tinkering" (Jacob 1977), and Maxam and Gilbert's (1977) techniques paper for DNA sequencing. However, besides truly landmark papers or theories that produced immediate and deep impact and changed science forever (i.e. Darwin's book (1859), Watson and Crick model (1953) or, Einstein's 1905 magic year), I regard the birth of new disciplines in a more microevolutionary stance. Moreover, the importance of Gould's book for Evo-Devo has been, to me, overstated (see below), while Maxam and Gilbert sequencing technique was as important for Evo-Devo as it was for other fields and, thus, of no such relevance as Gilbert claims.

Once genes and development were connected in the 70s, the link between development and evolution (or Evo-Devo) had, in my view, three clear forebears (Fig. 1). First in time, and in agreement with Gilbert (2003), was François Jacob's brilliant anticipation, back in 1977, that evolution do not behave as an engineer but as a tinkerer, which meant using what is at hand without creating anything new from scratch. Albeit theoretical, this idea anticipated

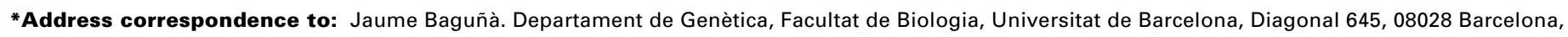
Barcelona, Spain. Fax: +34-93-4034420. e-mail: jbaguna@ub.edu

Final author-corrected PDF published online: 4th July 2008.

ISSN: Online 1696-3547, Print 0214-6282

(c) 2008 UBC Press

Printed in Spain 
the deep conservation of the genetic "tool kit" later found for all organisms. Prior to Jacob's conceptual leap, S. Ohno's book "Evolution by Gene Duplication" (1970) had already anticipated the first genetic mechanism to explain the evolution of morphological complexity. The second conceptual leap, and the first one in experimental terms, was the mutation screening of NüssleinVolhard and Wieschaus (1980) in Drosophila. This work represented the first "Big Science" experiment in Biology to uncover genes controlling specific processes in embryonic development. Later on, scores of these genes were critical to find their homologous counterparts in other organisms. Finally, finding of the first conserved stretches of DNA sequences among truly different organisms best exemplified by the Homeobox gene sequences (McGinnis et al., 1984a,b) had the farthest-reaching implications for Evo-Devo. In a mere 10-15 years crystallized the most important, yet totally unexpected and unanticipated, discovery of developmental biology as regards evolution: all organisms do have very similar genes in both kind and number (the basic 'genetic toolkit'; Carroll et al., 2001).

\section{Evo-Devo in Spain. A search in vain for ancestors and the first pioneers}

Evo-Devo is based on Embryology (Developmental Biology), Genetics (Developmental Genetics), and Evolution. Along the $19^{\text {th }}$ and the first half of the $20^{\text {th }}$ century, such fields were not developed, nor even existent, in Spain (Fig. 2A). Thousands of miles of coasts could anticipate, as it was in neighbour countries, the flourishing of marine biological stations. Roscoff, Banyuls, and Villefranche-surmer in France, Napoli in Italy, Kiel in Germany, and Plymouth in Great Britain were, like their counterparts in the United States (Woods Hole, Friday Harbour), places where most top quality comparative embryology was produced. As of today, there is still nothing similar in Spain. As regards Genetics, the first chairs and research groups were established in Barcelona and Madrid well into the 1960s, namely devoted to population genetics of Drosophila and corn. In other words, genetics in Spain lagged 50-60 years behind most western countries. Embryology (or Developmental Biology) had an even worse situation; no chairs nor specific departments were established, nor even exist today despite the presence of many active research groups. In turn, Developmental Genetics had to wait to early 70 s to witness the brilliant start of Garcia-Bellido's lab in Madrid. Finally, the reception to evolution in general and to darwinism in particular in $19^{\text {th }}-20^{\text {th }}$ century backward Spain was, despite a faithful handful, very harsh (Pelayo, 2002). Today, while research groups involved in evolutionary

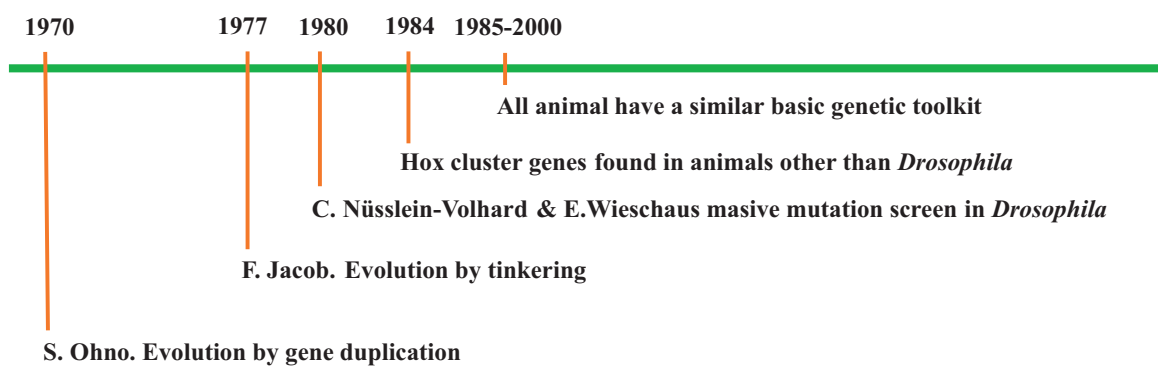

Fig. 1. Major conceptual leaps in the history of Evo-Devo. For further details, see text. studies are numerous, no Departments or Chairs specifically devoted to Evolution have yet been set.

In brief, no actual ancestors to modern Evo-Devo could be traced in Spain (Fig 2A). Even so, two exceptions (Fig. 2B)are worth mentioning (for an historical framework of Evo-Devo see Figs 3 and 4).

\section{Pere Alberch and the structuralist approach}

Born in 1954, Pere Alberch left Barcelona for the University of Kansas in the early 70s and joined David Wake's group in Berkeley in 1976. At 25 he became assistant professor at Harvard University and assistant curator in the Museum of Comparative Zoology. Following the wave of Eldredge and Gould (1972) model of punctuated equilibrium as an alternative to darwinian phyletic gradualism, and of Gould's models of heterochrony (Gould, 1977) which formalized the relationships between development (ontogeny) and evolution (phylogeny), Alberch, together with Gould, Oster, and Wake developed in mathematical terms Gould's models and produced a paper that soon became a classic (Alberch et al., 1979).

Late 1970s-early 1980s were still pre-developmental genetic years. The paucity of genetic data and a deep and growing dissatisfaction with gradualistic microevolutionary models, led several groups, namely in the USA, to develop a hierarchic, structuralist view of development and evolution. In their view, genes are at a primary low tier level coding for proteins and within the genome there are hierarchical subdivisions with genes interacting in complex, albeit undisclosed, ways to control patterns of protein production. In an upper second tier are second order interactions that, while resulting from the presence of primary gene products, show their own hierarchies governed by essentially independent rules (i.e. by the physicochemical properties of molecules). This rules define cell properties like adhesion, motility, contact guidance, inhibition, inductive interactions, etc,.. Finally, they recognized a final upper third tier where specific sets of tissue interactions occur which, while their molecular basis is unknown, do limit and constrain development. Overall, all this second order (epigenetic) phenomena link the genome to the embryo and ultimately to the species' phenotype.

While acknowledging that genes are important components of developmental and evolutionary systems, Alberch and co-workers tuned down their actual role paying more attention to phenomena constraining developmental changes (and hence evolution) to offset the overwhelming power given to natural selection by population geneticists. Among these constraints were the stability of developmental systems (i.e. many genotypes resulting in the same phenotype), the directionality of evolutionary transformations (i.e. some transformations occurring more commonly than others and some never seen), and the limits on patterns of morphogenesis set by molecular mechanisms of cell-cell interactions (i.e. branching in lungs, kidneys and liver is only carried out by epithelial sheets and not by mesenchymal cells, etc.). Translated into evolution, developmental constraints were the basis of discontinuities and clumpings in phenotypic morphospace and a way to explain the stability of many lineages and morphological 

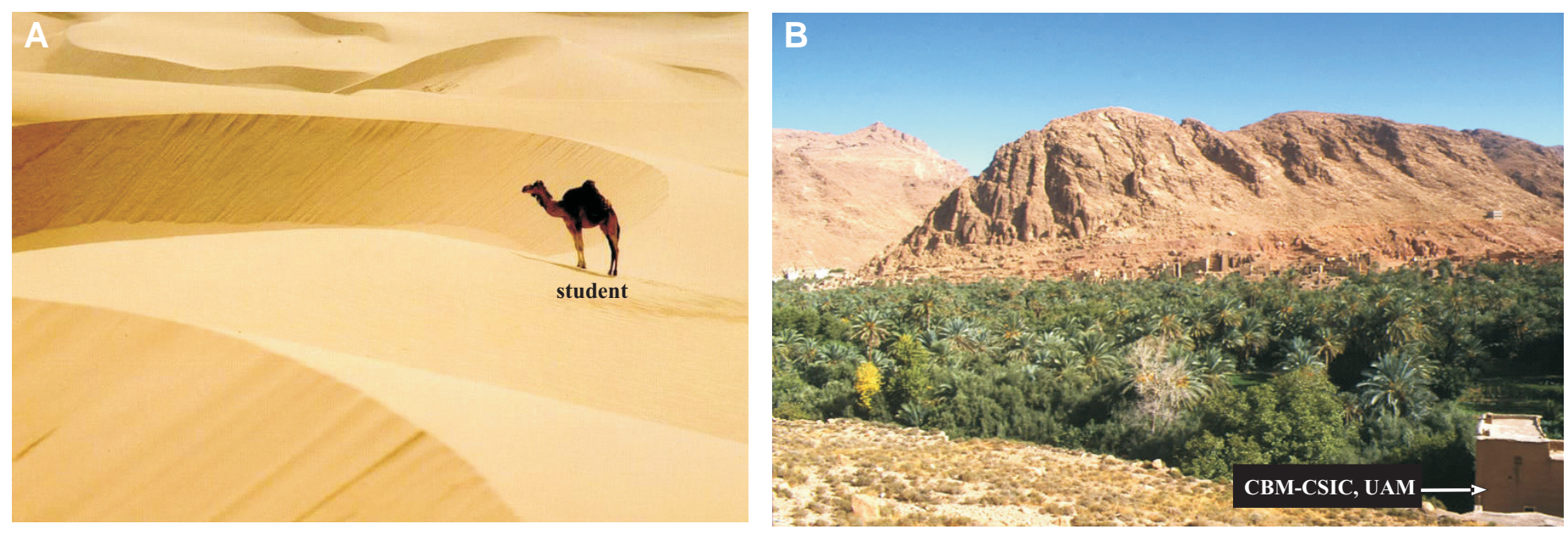

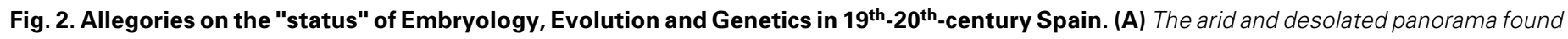
by the few students interested in Embryology and Developmental Biology in Spain from the 1850s to the 1960s. (B) The first oasis in Developmental Biology and Developmental Genetics produced in Spain circa 1970: the Centro de Biologia Molecular (CBM-CSIC, Universidad Autónoma de Madrid).

patterns (stasis) in geological times. Furthermore, to account for the swift and accelerated (macroevolutionary) transitions contemplated in Eldredge and Gould's punctuational equilibrium theory during speciation, heterochrony (developmental differences in timing among related species), in all its forms and variations, provided a swift and integrated mechanism to transform one form into another.

These views were best encapsulated in the proceedings of the Dahlem Conference of 1982 ("Evolution and Development", J.T. Bonner ed, 1982; Alberch, 1982). In bare terms, to have a satisfying explanation for both development and evolution going beyond natural selection and gradualism, they urged to uncover the generative rules of development; that is, a hidden set of laws and principles yet to be discovered connecting the hierarchical tiers (the 'structure') mentioned above. In this endeavour they worked together with theoreticians and mathematicians who developed sophisticated models which accounted for a wide array of developmental phenotypes: zebra's stripes and cats' spots, pattern segmentation in insects, gastrulation movements (Odell et al., 1981), bifurcations in reaction-diffusion mechanisms, or mechanoelastic mechanisms giving rise to epithelial placodes and evaginations or foldings (Oster and Alberch, 1982). Moreover, heterochronic processes, single or combined, were called upon to explain a plethora of evolutionary transitions from drastic shifts in morphology due to progenesis or neoteny to subtler changes produced by hypermorphosis, pre- or postdisplacement and their combinations therein.

Later on, Alberch's work concentrated on the basic organization and evolution of the tetrapod limb. He described a hierarchical sequence in cartilage formation that, according to internal rules of construction, could be explained by three types of events: condensation, branching, and segmentation (Shubin and Alberch, 1986). This model represented a radical departure from previous ones and furnished an ingenious explanation for the appearance of the autopodium (hands and feet in tetrapods). This novel structure originated from the bending towards the anterior of the metapterigial proximodistal axis of fishes forming the so-called "digital arch". From this arch digits sprang, those in anterior positions (i.e. thumbs and big toes) corresponding to the most distal region of the limbs. He also studied the order of digit reduction in several species of anurans and in other vertebrates. Later developments in molecular, cellular and experimental embryological, however, indicated that limb development does not involve a branching mechanism and also contradicted that digits arise by bifurcation from a digital arch (Shubin et al., 1997). Moreover, careful studies on digit disappearance show it to be due to processes of construction followed by destruction than to actual constraints of development (Galis et al., 2001).

In the late 80 s Pere Alberch came back to Spain as research professor of the CSIC and in 1989 became director of the Museo Nacional de Ciencias Naturales (MNCN) in Madrid. In the meantime, however, the impact and influence of theoreticians to model developmental processes faded, due in part to the illogicality of biological mechanisms and to the new tools furnished by developmental geneticists to solve problems. In a particularly well known example, the years spent making scores of mathematical models of how Drosophila made its segments, were blown away by a single experiment that showed that the actual mechanism did not fit any of the models suggested. On the other hand, as Gould himself acknowledged, two very basic tenets of punctuated equilibrium were shown to be wrong; namely, the direct acceleration of evolutionary rate by the process of speciation (cladogenesis), and the notion that stasis is due to internal resistance to natural selection (Futuyma, 2002).

In 1995, Pere Alberch left the directorship of Madrid MNCN. In 1997, when he was planning to move to Valencia to start a new research program he untimely died at the early age of 43 . Despite the bulk and most influential research he carried out was done outside Spain, he should be considered one of the first, and great, synthesizers of development and evolution in the world and, by any account, the first spanish.

\section{Important Evo-Devo ideas stemming from the Madrid School of Developmental Genetics}

The early 70 s were times of excitement in the new developmental genetics labs in Madrid (Fig. 2B). Back from a postdoctoral stay at the California Institute of Technology (Caltech) (1967-69), Antonio García-Bellido, together with Ginés Morata and Pedro 
Ripoll, start his seminal work using clonal analysis in Drosophila that led to the finding of compartments (polyclones of cells determined to give specific parts of the imaginal discs and the adult cuticle; García-Bellido et al., 1973). Compartments are determined by the binary activation (on/off) of specific genes, later dubbed selector genes (Garcia-Bellido, 1975). At the end of this process of compartmentalization, each compartment has a specific combinatorial state of selector gene activation. Selector genes, which are Hox (homeobox-containing) genes, control the activity of different sets of down-stream genes, called realisators. Because the later seem to control scores of basic cell parameters (adhesion, proliferation, movement, differentiation), different combinations of selector genes in each compartment would give rise, through the differential activity of realisators, to different morphologies. The stage was set to think on how changes in selector genes could be instrumental in changing morphologies and, hence, driving evolution.

Two main ideas arose. First, García-Bellido (1977) suggested that selector genes evolved to repress, in the presence of specific inductor molecules, a primitive developmental pathway. Because the thoracic pathway was considered archetypal (primitive or plesiomorphic), the action of selector genes changed homogeneity (i.e. sequential repetition of identical segments or metameres like in primitive insects) into diversity such as segments with specific characteristics of head, thorax and abdomen of advanced insects. When selector genes become inactive by mutation, the alternative (homeotic) pathway, the thoracic one, appears. Similar considerations were applied to homeotic transformations affecting appendages, which lead to suggest that anterior, dorsal and proximal pathways are archetypical and that homeotic mutations could be considered atavic since the archetype they uncover is presumably related to a phylogenetically more primitive condition.

In 1978 Ed Lewis published a seminal paper suggesting that homeotic genes patterning the Anterior-Posterior axis in Drosophila were linearly ordered (clustered) in the genome showing a striking spatial correlation with the body regions transformed by specific mutations of these genes (Lewis 1978). He suggested this gene cluster originated by successive tandem cis-duplication in an evolutionary line from an ancestor bearing a single homeotic gene. Such scenario fit Garcia-Bellido's proposal on the evolution of selector genes as regulators of A-P body patterning. However interesting, such views were soon contested. First, instead of a one-to one correspondence between genes in the Bithorax gene cluster and body segments, only three genes were found to control a much larger number of thoracic and abdominal segments (Sanchez-Herrero etal., 1985). In other words, many of the numerous genetic elements inferred by Lewis were due to lesions in the regulatory regions of these three genes. Second, homeotic genes had a short (180 nucleotides) stretch of DNA, the homeobox, (McGinnis et al., 1984a), soon to be find in all arthropods and many other invertebrates and vertebrates, segmented or not (McGinnis et al., 1984b). Hence, most selector genes did not actually evolve within insects. Therefore, their role, namely that of Hox-cluster genes, is very ancient and likely involved to specify antero-posterior position irrespective of morphology. Third, most selectors tested do not regulate realisators directly but they do it indirectly through a small intermediate set of genes called regulators (Castelli-Gair and Lovegrove, 2003). This is more in line with new ideas that see microevolutionary adaptation coming first and Hox expression shifting a bit later to make the new body pattern more efficient or more stable (Budd, 1999; 2006), than with the former view of body patterning genes (i.e. selector genes) driving morphological change.

A second set of ideas stemmed from the comparative anatomy of cuticular patterns (namely bristle patterns) and wing venation patterns in Drosophila. Mutants altered patterns by suppression, addition, substitution or disruption of bristle pattern elements or vein patterns. Some pattern mutants resembled patterns shown by phylogenetically more ancestral species (García-Bellido, 1983); others appeared in branches unrelated to each other, suggesting convergent evolution driven by adaptive selection. In line with the extant anti-gradualistic atmosphere, but at the same time skipping macromutational events, García-Bellido postulated the presence in wild populations of different, selectively neutral, allelic variants of genes with slight morphological effects. When specific combination of alleles from different genes occurred new patterns developed. This explained the sudden appearance of new morphs, while avoiding macromutation as mechanism and selection as the driving force (García-Bellido, 1983).

Later, several labs in Spain and elsewhere concentrated to find the main genes controlling bristle and venation patterns in Drosophilaand their interactions (summarized in García-Bellido and De Celis, 1992). In parallel, Juan Modolell' group, also at the Centro de Biologia Molecular in Madrid, showed that bristles develop from groups of precursor cells (proneural groups) that depend on the expression of the-Achaete-Scute genes (summarized in Campuzano and Modolell, 1992). Most of these genes were found in other organisms in which they played similar or related roles. Thus, the stage was set to find how temporal and spatial changes in the expression of bristle and vein genes, as well as in pigmentation genes, among closely related species could explain the pattern differences among them.

After a decade of intense work, much done outside Spain, vein, bristle and pigmentation genes were found to be regulated by upstream selector and other regulator genes conforming a very complex "trans-regulatory landscape" (Prud'homme et al., 2007; Simpson, 2007) established during early development. Because changes in this landscape would be highly pleiotropic, novel patterns arise more readily from the recruitment of cis-regulatory regions (by non-homologous recombination) or by evolving (by a single or few mutations) new cis-regulatory regions in bristle, vein, or pigmentation genes to which existing trans-regulatory proteins may bind, than by de novo creation of new genes or of entirely new cis-regulatory regions. In this way, fitness penalties are minimized because only a specific aspect of a gene function is affected while leaving intact the other functions (Prud'homme et al., 2007).

\section{The impact of molecular phylogeny on Evo-Devo. From ribosomal gene sequences to phylogenomics}

Although phylogenetic relationships have not been considered important to study developmental mechanisms, they become it so when the evolution of developmental processes is considered. As Raff (2000) clearly states, phylogeny provides three important kinds of information: 1) it can determine the direction in which developmental features evolve; 2) it allows evolutionary rates to be inferred; and 3) allows homology 
statements or, conversely, show that apparent homologous features are not so. Points 1 and 3 have deep implications on Evo-Devo as they help to determine the "true" groups before and after a morphological novelty and so to avoid mistaken comparisons of gene expression patterns in non-homologous features.

\section{The new Animal Phylogeny}

The advantages of gene sequences as phylogenetic characters (molecular phylogeny) compared to morphological characters have been amply discussed and was first shown to work in prokaryotes using the $16 \mathrm{~S}$ ribosomal RNA subunit (Woese et al., 1978). This success was soon extended to eukaryotes, metazoans among them, by sequencing their 18S rRNA subunit. The first important contribution was from Field et al. (1988), and was followed by scores of works that brought important findings, some of which strongly contested several basic tenets of morphologically based animal trees (Aguinaldo etal., 1997; Adoutte etal., 2000). Among several major changes and shifts (i.e. the demise of the Articulata, the grouping of the lophophorates with the protostomates, and the split of the later into Lophotrochozoa and Ecdysozoa) two are worth to stress. First, acoelomates (basically the Platyhelminthes and the Nemertea) were brought, through $18 \mathrm{~S}$ rDNA, within a new protostomate superclade, the Lophotrochozoa, made by all phyla with spiral cleavage and the lophophorate deuterostomates. Second, pseudocoelomate clades, or 'Aschelminthes', exploded with some groups (Nematoda among them) together with Arthropods and related groups forming the new superclade Ecdysozoa, whereas other phyla took uncertain positions either with lophotrochozoans or with ecdysozoans. In summary, the new animal phylogeny split the Bilateria into three big superclades: the old Deuterostomia, and the protostomates split into the new Ecdysozoa and Lophotrochozoa. The new paradigm was reinforced when genes from the Hox cluster of key metazoan groups were sequenced (see below). All bilaterian studied, including pseudocoelomates and acoelomates, had a number of Hox cluster genes of, at least, 7-8 genes.

\section{A case study. The first bilateral organisms: simple or complex? The role of the Barcelona Molecular Phylogeny group}

The new Animal Phylogeny had important consequences as regards the main morphological and embryological features of the Last Common Bilateral Ancestor, or LCBA. According to the new phylogeny, the LCBA was a rather complex organism with clear body axes, one-way gut, brain and nerve cords, coelom, segments, eyes, some sort of appendages, and a full set of Hox-cluster genes (Carroll et al., 2001). Therefore, acoelomate and pseudocoelomate bilaterians, formerly placed at the base, were now displaced well within the bilaterian tree and had to originate by secondary reduction from coelomate, segmented ancestors. Although the transition from simple radial diploblasts to this complex bilateral was left open, the new paradigm backed the old archicoelomate (now renamed the 'complex

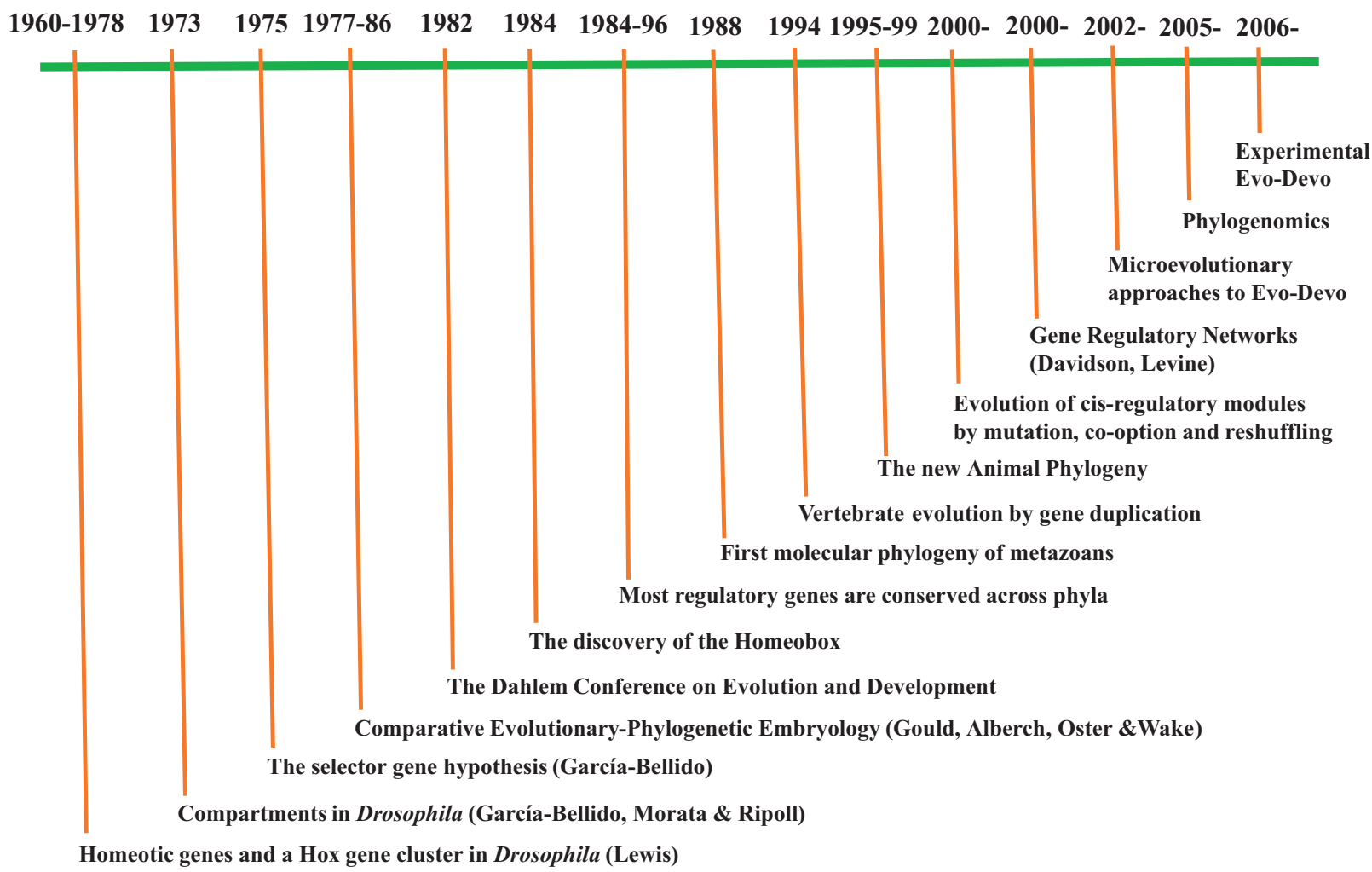

Fig. 3. Landmarks in Evo-Devo research. Discoveries whose finding could be attributed to a single or a few researchers have their names shown in brackets. For further information, see text. 
Urbilateria') hypothesis (see Willmer, 1990; and Valentine, 2004, for comprehensive summaries) in front of the alternative planuloidacoeloid hypothesis (for thorough reviews on the later see SalviniPlawen, 1978; Baguñà and Riutort, 2004a; and Baguñà et al., 2008a,b).

In all schemes about the early history of bilaterians, the flatworms (phylum Platyhelminthes) had a central role - its simple morphology (acoelomate, non segmented with a blind gut) coupled to the gradualistic view of evolution have made them the perfect transitional taxon from cnidarian diploblasts to bilaterian triploblasts. Their monophyly, however, has always been into dispute. To clarify this problem, the Molecular Phylogeny group at the Department of Genetics of the University of Barcelona led by Jaume Baguñà and Marta Riutort, the first group in Spain to introduce ribosomal sequences into metazoan phylogeny, produced the first comprehensive molecular tree of the Platyhelminthes and other bilaterian phyla using 18S rDNA sequences (Carranza et al., 1997). Later, they analyzed in depth the position of platyhelminth acoels within a large set (60 species) of bilaterian and other non-bilaterian phyla. Both results run contrary to morphological analysis: Platyhelminthes was polyphyletic such that acoel and nemertodermatid flatworms (two orders of Platyhelminthes sensu lato) were basal bilaterians (Ruiz-Trillo etal., 1999) whereas Platyhelminthes sensu stricto consisted of Catenulida+Rhabditophora and belong to the new superclade Lophotrochozoa (reviewed in Baguñà and Riutort, 2004b). Such results were also at variance to one of the basic tenets of the new animal phylogeny: the non-basal position of acoelomate organisms. Nonetheless, the basal position of acoels and nemertodermatids was further corroborated from sequences of other nuclear genes (including Hox-cluster genes), mitochondrial genes, phylogenomic analyses using EST sequences (Philippe et al., 2007), and microRNA sets (Sempere et al., 2007; reviewed in Baguñà et al., 2008b). Moreover, recent molecular phylogenies of the three big superclades including most extant phyla show, in contradiction with the new animal phylogeny (Adoutte et al., 2000; Carroll et al., 2001), that most acoelomate and pseudocoelomate branch early within each superclade (Ruiz-Trillo et al., 2002; Jondelius et al., 2002; Bourlat et al., 2006: Wallberg et al., 2007)

The comeback of acoelomate and pseudocoelomates at early branching positions within the Bilateria and within each of the three big superclades better fits a gradualistic view of animal evolution and hypotheses (i.e. the planuloid-acoeloid; Salvini-Plawen, 1978) linking simple radial diploblasts to simple bilaterians. Moreover, it is currently helping to polarize key characters (i.e. segmentation, coelom formation, one-way gut, excretory system, etc.) and to determine their origin in animal evolution (see below).

\section{Other works}

Besides the big animal phylogeny, molecular phylogenies have also dealt with more restricted evolutionary problems that, nonetheless, have major implications for Evo-Devo. Among those carried out in spanish labs or by spanish people abroad are those dealing with the phylogeny of protostomates (Ecdysozoa and Lophotrochozoa) (Giribet et al., 2000), the different hypotheses on the internal phylogeny of arthropods (Giribet and Ribera, 2000; Giribet et al., 2001), the application of EST collections to the Articulata (Coelomata) vs Ecdysozoa controversy (Dopazo and Dopazo, 2005), and studies on the origin and phylogenetic relationships of vertebrates in general and of living amphibians and turtles in particular (reviewed in Meyer and Zardoya, 2003).

\section{The two stages of recent Evo-Devo: from the "basic genetic toolkit" and "functional homology" to assem- bling developmental genes into gene networks and developmental mechanisms}

The astonishing finding that most regulatory genes are conserved across phyla generated a lot of excitement, a lot of controversies, and set the pace and the agenda of modern Evo-Devo. In a first stage, a basic idea was upheld: if in two different species orthologous genes are expressed in a similar and specific manner, these expression areas or regions are considered homologous, even across phyla, and should have been present in their last common ancestor. Examples included the antero-posterior patterning mechanism with HOX genes, the genes involved in dorsalventral patterning, eye formation, "heart" tissue induction, the immune system, segmentation, appendages, etc,.. (Martindale, 2005), and led to formulate some educated guesses about the tool kit present in ancestors and the morphological characters set by them (Carroll et al., 2001). Moreover, successful gene swapping experiments, often across wide phylogenetic distances (i.e. Drosophila vs the mouse and vice versa) strengthened the case for homology among the structures in which these genes functioned. The notion of "functional homology" was coined to interpret shared patterns of gene expression as evidence of morphological homology.

This initial enthusiasm proved premature and led to a second, more restrained, stage. Thus, while in invertebrates (i.e. in insects) expression of individual Hox genes is linked to segment number, in vertebrates, the Hox gene expression pattern is linked to segment identity rather than segment number. Further, Hox gene expression in deuterostomate hemichordates is staggered along the A-P axis though it patterns a very different morphology (actually the non segmented trunk) than in insects and vertebrates (Lowe et al., 2003). In other words, Hox genes specify position along the A$P$ body axis but not specific morphologies. Similar arguments could be put forward for other genes like Distalles or DII, patterning every sort of appendage, and Pax6, considered a master gene for eye formation in all phyla. Another source of confusion is that most developmental genes are expressed in non-homologous structures during development. This is due to recruitment, or co-option, of most developmental genes to play different roles driven by scores of cis-regulatory regions that bind different trans-regulators. While this confers a bewildering array of possibilities and is the source of much variation, it makes problematic to establish correct homologies. To be proven true, homologies might be independently sought at every level of biological organization (i.e. genes, gene expression patterns, embryonic origins and morphological structures; Abouheif, 1997).

Two recent findings best exemplifies this baffling situation. First, the diploblastic (bearing only ectoderm and endoderm) and radial (no dorsal-ventral axis) cnidarians bear most of genes expressed in the mesoderm and in the D-V axis of bilaterians (Martindale et al., 2004; Matus et al., 2006); conversely, although cnidarians possess several different kinds of 'eyes' do not possess "the eye gene" Pax6 (Matus et al., 2007). Second, Porifera (sponges) lack organs and nervous system but possess a nearly complete set of post-synaptic proteins homologs that assemble into a complex 
structure (Sakarya et al., 2007). Therefore, there are no such things as "mesodermal", "eye", "segmentation", or "limb" genes; what we have are just molecules that bind to DNA, interact with each other, form multimeric complexes, etc. Further, the developmental or morphological outcome of a single gene or genetic pathway cannot a priori be predicted; on the contrary, the potential association between any transcription factor and any downstream gene is readily emerging as a major operational principle of most regulatory systems (Prud'homme et al., 2007).

To go beyond claims of homology based on the ill-fated concept of "functional homology", the task of current Evo-Devo is, assuming a common "toolkit" of genes from sponges to man, to ask the question of how and when these genes were assembled into interacting networks (or kernels in Davidson and Erwin, 2006, parlance) to determine the formation of regional and/or tissue specific identities. Sampling key genes at differences places in highly supported metazoan phylogenetic trees would allow us to determine when, and how, these networks were put together.

\section{Contribution of Spanish groups to modern Evo-Devo}

In what follows we summarize examples of work bearing on the issues stated above carried out in labs of Spain, or abroad by spanish people (see Fig. 4).

\section{The quest for the first chordate and the first vertebrate}

In pre-cladistic terms, 'vertebrates' include mammals, birds, reptiles, amphibians, true fish, lampreys and hagfish. Despite they are not particularly species-rich, they comprise the biggest and on every respect most complex organisms on Earth. No wonder their origin has been the subject of debates and controversies for over a century. While many ancestors to vertebrates have been suggested, only cephalochordates (the amphioxus or lancelet) and urochordates (tunicates, salps, etc.) have attracted interest because they share with vertebrates some important embryological characters (notochord and dorsal hollow neural tube). For much of the $20^{\text {th }}$ century, the prevalent scenario as regards the origin and evolution of chordates and vertebrates contemplated an ancestral ascidian originated from the presumed deuterostomate ancestor, a sessile lophophorate-like animal. In turn, the larva from this ancestral ascidian gave rise by paedomorphosis to the ancestor of both cephalochordates and vertebrates. Thus, cephalochordates were seen as the proxy of how a pre-vertebrate looked like or, alternatively, as a sort of degenerate vertebrate.

Soon after Hox cluster genes were found in vertebrates and invertebrates, it became evident that all vertebrates examined had four copies of the Hox cluster (named A to D) situated in different chromosomes. Because invertebrates examined at that time (actually Drosophila and C.elegans) had a single cluster, it was postulated that close to vertebrate origins gene cluster duplication took place (Holland et al., 1994). This prompted to examine the Hox-cluster content of the amphioxus. In 1994, García-Fernàndez and Holland, reported that in contrast to the multiple Hox gene clusters of all vertebrate examined, amphioxus possess a single cluster (García-Fernàndez and Holland, 1994). At that time, Jordi García-Fernàndez, from the University of Barcelona, was a

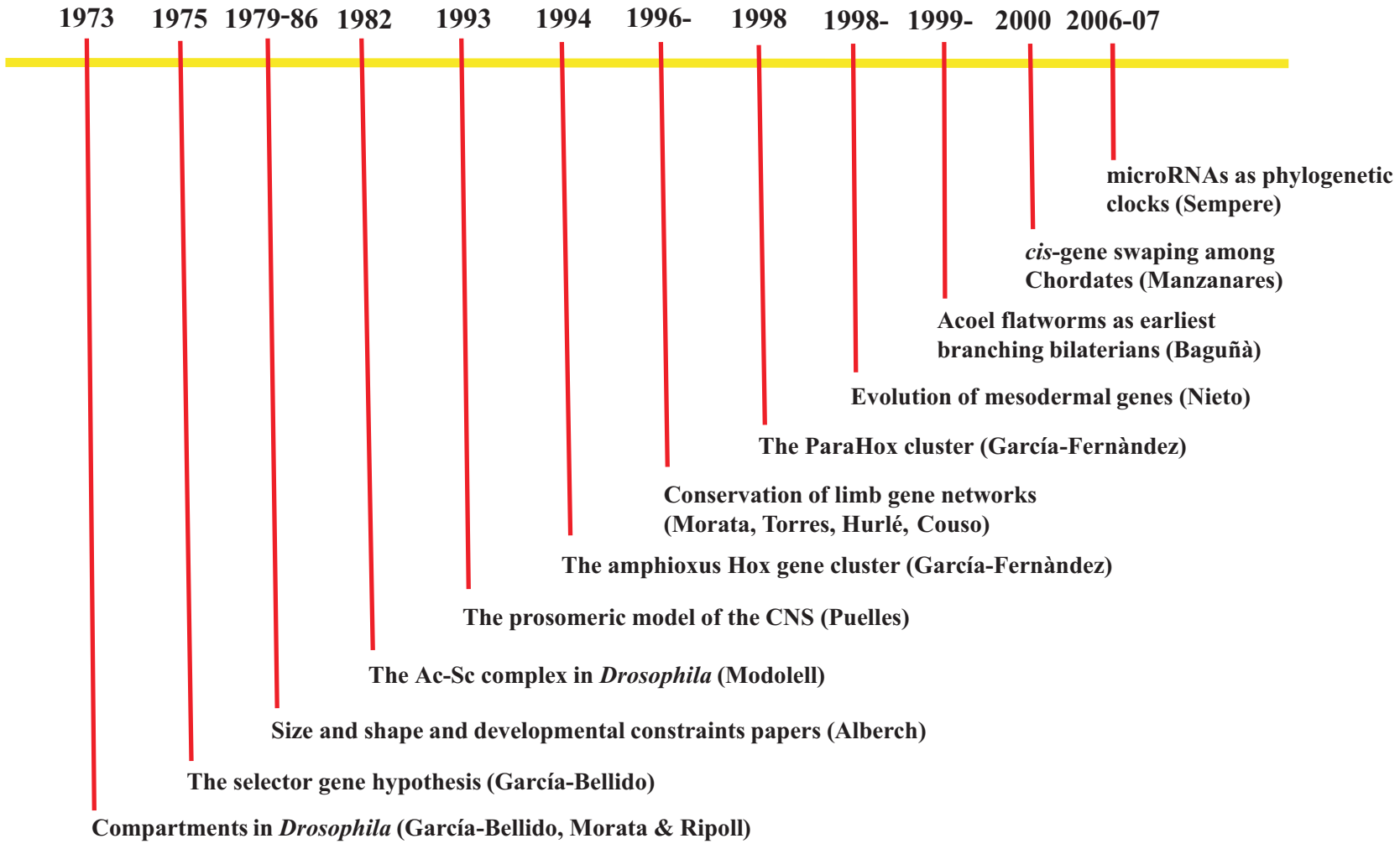

Fig. 4. Main contributions to Evo-Devo by Spanish researchers, working in Spain or abroad. For the sake of simplicity and clarity, only leading Spanish authors or investigators are indicated (in brackets). For further information, see text. 


\section{J. Baguñà}

postdoctoral researcher in Peter Holland's lab in Oxford. Initial studies of the cluster revealed an organization very similar to the inferred pre-duplication condition that must have been present in the long-extinct ancestor of vertebrates. Further sequencing showed the presence of additional posterior genes close to the Evx homeobox genes.

In 1998 a new Hox-like gene cluster, sister to the first was described by Holland's and García-Fernàndez groups in the amphioxus and dubbed the ParaHox cluster (Brooke et al., 1998). The ParaHox gene cluster comprised 3 linked genes, homologous to the anterior, third, and posterior groups of the Hox gene cluster. Preliminary expression data suggested it might pattern in a colinear manner the endoderm in a similar way as the Hox gene cluster patterns the ectoderm and the nervous system. From then on, several models and hypotheses were elaborated to account for the evolution of both clusters from a hypothetical ProtoHox cluster (for a review, see García-Fernandez 2005). As of today no consensus exist as regards to any of these models.

Recent phylogenomic analyses (Bourlat et al., 2006) now position cephalochordates as the basal group within the Chordata, while urochordates and vertebrates diverged later. In other words, the ancestor of chordates presumably looked like an amphioxus. Moreover, analyses of axial patterning systems in amphioxus, vertebrates and hemichordates (a non-chordate deuterostomate) and the results of the new animal phylogeny, has replaced the presumed sessile lophophorate-like organism as deuterostomate ancestor by a free-living, bilateral worm-shaped organism, with gill slits and a post-anal tail.

This places the amphioxus into a key position to understand the biology and evolution of deuterostomates in general and of chordates and vertebrates in particular. As an example, although amphioxus has no neural crest and, therefore, no homologues of vertebrate organs derived from it, it has all the genetic machinery to generate neural crest. This was clearly shown by Miguel Manzanares and colleagues working at Krumlauf's lab in Mill Hill, London (Manzanares et al., 2000). They introduced cis-regulatory sequences from amphioxus Hox genes linked to a gene encoding a reporter protein into the cells of mouse or chick embryo. As expected, the amphioxus reporter was expressed in the developing hindbrain, but unexpectedly it was also expressed in the neural crest and the neurogenic placodes, even though amphioxus lacks both crest and placodes. Therefore, the evolution of neural crest in vertebrates cannot be due to the gain of a new regulatory gene but to the assembly of pre-existing genes into a genetic network controlling the migratory behaviour of cells close to the neural tube. This situation in amphioxus reminds that of cnidarians and sponges which despite having 'mesodermal', 'dorsal-ventral' and 'post-synaptic' genes they do not have a true mesoderm, a clear D-V axis, and nervous system (in sponges). This indicates the analysis of how existing genes assembled into functional networks controlling specific tissues, organs and developmental processes, as one of the hottest topics of Evo-Devo today.

\section{Searching the molecular blueprint of the first bilaterians}

The finding that acoelomorph flatworms are, very likely, the earliest branching clade of bilaterians (Ruiz-Trillo et al., 1999; Baguñà and Riutort, 2004a), suggest they might display the features expected for their position between cnidarians and higher bilaterians (or Eubilateria). This begs the question of how genes already present in the conserved 'toolkit' of all metazoans were incorporated into interacting networks responsible for bilaterian features present in acoelomorphs but not in cnidarians (i.e. mesoderm, a clear D-V axis, anterior clustered nervous system), and/or whether new genes were necessary. The search for Hox genes in four acoelomorph species (Cook et al., 2004; Jiménez-Guri et al., 2006; Hejnol and Martindale, personal communication; Moreno, Baguñà and Martínez, unpublished data) showed the presence of a reduced set of Hox genes: 1-2 from the anterior class, a single posterior, and 1-2 from the central class). Interestingly, central class Hox appears to be absent in cnidarians (Ryan et al., 2007). Moreover, the ParaHox central Xlox-ortholog and a posterior $\mathrm{Cdx}$-ortholog have also been found in acoelomorphs (Cook et al., 2004; Jiménez-Guri et al., 2006); in contrast, Xloxorthologs are absent from cnidarians. Finally, recent surveys for microRNAs in cnidarians, acoels, protostomates (including Platyhelminthes sensu stricto), and deuterostomates show that the number of miRNAs in acoels (6) is intermediate between a smaller set in cnidarians (2/3) and the larger and expanding set in the rest of bilaterians (from 20-25 up to more than 300 in chordates) (Sempere et al., 2006, 2007). Therefore, for Hox cluster genes and different miRNAs, the transition from radial and diploblast to bilateral and triploblast meant increasing numbers in both of them.

Current work on the expression of the most important developmental genes in acoels during the embryonic development indicate that while some genes show patterns similar to one would have predicted from the Protostomate-Deuterostomate Ancestor (PDA), others are more similar to the patterns found in cnidarians (Hejnol and Martindale, 2008). Although preliminary, these results suggest that while some gene networks specifying bilaterian features had already been assembled in acoels, others had to wait until a more complex PDA appeared (Denes et al., 2007). In addition, this supports again the intermediate key position of acoelomorphs, between the diploblast cnidarians and the more advanced triploblastic eubilaterians.

\section{The roles of gene duplication, modularity and reshuffling. The Snail gene superfamily as a case study}

The Snail family of zinc-finger transcription factors play a role in early embryonic development of vertebrates and invertebrates, with conserved early roles in gastrulation and mesoderrm patterning, and derived later roles in neural differentiation and vertebrate neural crest formation. A snail ortholog is already found in the cnidarian Nematostella vectensis where it is expressed at gastrulation and endoderm formation (Martindale et al., 2004). The Snail family has expanded by gene duplication in different invertebrates (i.e. Drosophila) and in all vertebrates. In the later, its role in neural crest formation, believed to have been crucial in the formation of the "new head", has recently attracted much attention.

Amphioxus and tunicates (ascidians) have a single snail gene that is expressed in the dorsal neural tube and in the tail bud mesenchyme. Despite the presence of some migratory neurons and pigment cells, both lack a bona fide population of neural crest cells and, accordingly, a proper vertebrate head. Therefore, the neural crest is a clear vertebrate innovation. Amphioxus contains all the major transcription factors de- 
ployed in the vertebrate neural crest regulatory network (epidermal and neural ectodermal markers, neural plate border specifiers, neural crest specifiers (snail among them), and some downstream mediators of neural crest migration and differentiation). However, some genes involved at later stages of neural crest differentiation are lacking (Sauka-Spengler and Bronner-Fraser, 2006). Question is while having most elements to build a neural crest, cephalochordates and urochordates have not developed it.

Large-scale genome duplication events seen at the dawn of vertebrates might bring some answers. Many neural crest specifier genes have several paralogues in vertebrates whereas amphioxus usually has a single copy. Therefore, neofunctionalization of some paralogues may have facilitated the co-option of genes into a neural crest gene network in vertebrates. In addition, another mechanism, dubbed subfunctionalization, or DDC model ("duplication-degeneration-complementation"), might also had a role. It implies the occurrence of complementary degenerative mutations causing the differential loss of cis-regulatory elements in each duplicate. The result is that the original functions are now nonredundantly distributed between the paralogues.

During neural crest formation, snail inhibits the expression of $\mathrm{E}$-cadherin and cell cycle genes and induces the so-called epithelial-mesenchymal transition (EMT). The group of Angela Nieto, formerly at the Instituto Cajal in Madrid, nowadays at the Instituto de Neurociencias of Alicante, has been particularly active analyzing this role (Cano et al., 2000) and specially the changing functions of snail genes after duplication in different vertebrates (Locascio et al., 2002; Barrallo-Gimeno and Nieto, 2006). In the later, they analyzed the expression of Snail and Slug, another gene of the family, in embryos of dogfish, zebrafish, turtle, lizard, chicken and mouse. These genes were found expressed at multiple sites in all species, such as neural crest, cranial mesenchyme, branchial arches, mesoderm, limb buds and tail bud mesenchyme. In some domains both genes overlapped, whereas in others they were unequally distributed. Moreover, Slug was expressed in a new specific domain, the lens, which is a synapomorphy for all vertebrates. When the expression of both genes was mapped onto the consensus phylogenetic tree of vertebrates (reviewed in Meyer and Zardoya, 2003), neither neofunctionalization nor the DDC model could account for all changes. Either reversal of degenerative mutations or de novo creation of tissue-specific regulatory elements shall be called upon. However, under the much overstated Dollo's law, such reversals are very unlikely or impossible though this has recently been questioned (Prud'homme et al., 2007). Another way to explain the phylogenetic distribution of gene expression characters is reshuffling by crossing-over, interchange or gene conversion.

In any case, the analysis of Snail/Slug by Nieto and colleagues has uncovered a much greater plasticity and complexity than expected. Importantly, it is also a warning against using expression or function as phylogenetic characters when studying the evolution of gene families, as well as a reminder that irreversible loss (or modification) in the activity of cis-regulatory elements is not a fixed feature of duplicated gene history and may happen more than once in the evolution of a single genetic system. Finally, as recently shown in the pigmentation spot pattern system in Drosophila (Prud'homme et al., 2006), some results in Snail/Slug are also compatible with the reappearance, by back mutations or by de novo creation of new regulatory modules, of expression domains after their loss at earlier stages in evolution.

\section{Homologous genes, homologous structures. The patterning of the vertebrate Central Nervous System}

The best scenario for Evo-Devo studies appears when homology occurs at all four levels of biological organization (genes, gene expression patterns, embryonic origins, and morphological structure; Abouheif, 1997) in all taxa compared. In these examples, homologous genes pattern homologous morphological structures. Hence, changes in the expression of such genes should transform or elaborate morphological structures to perform different or more complex functions.

A fine example of this scenario is the basic pattern of the Central Nervous System (CNS) in vertebrates. In the wake of Nüsslein-Volhard and Wieschaus screenings and the finding of the homeobox in Drosophila, scores of orthologous genes were found in most vertebrates. As in the Drosophila embryo, the expression of homeobox and other regulatory genes were found to delimit the segment boundaries of the seven or eight discrete units (rhombomeres) in the hindbrain of vertebrates. As for the more anterior parts, the fore- and midbrain, their complex morphology and histology hindered to recognize whether it was truly segmented. A century-old school of neuroembryology postulated that segmentation, as seen from the presence of transverse constrictions in the wall of the neural tube in several species, contributed to subdivide functionally the CNS into distinct domains (the neuromeric model). Such tenets, however, were not generally accepted.

In the early 90 s, several groups, prominent among them that of Luis Puelles from the University of Murcia, tested in the anterior brain of mouse and chicken the expression of vertebrate orthologues of genes known to pattern the head of Drosophila. Such genes were found expressed in regionally restricted patterns leading them to suggest that the forebrain was segmentally organized into six transverse domains named prosomeres ('prosomeric model'; Puelles and Rubenstein, 1993). Prosomeres were grouped into prosomeres $p 1$ to $p 3$ making the diencephalon, and p4 to p6 making the secondary prosencephalon. In addition, the forebrain was also organized into nonoverlapping longitudinal domains parallel to the longitudinal axis of the neural tube. These domains are analogous to the roof, alar, basal, and floor of the spinal cord. Prosomeric and longitudinal boundaries (DV boundaries) matched the expression boundaries of several genes. Further, some of boundaries were found to have organizing properties.

The prosomeric model was readily accepted. By contrast, the number and limits of some prosomeres (i.e. p4 to p6 or just a single non segmented prosomere) remains controversial (reviewed in Puelles and Rubenstein, 2003). Importantly for EvoDevo studies and for the evolution of CNS structure and function in vertebrates, the prosomeric model seems well conserved in other vertebrates, from amphibians to mammals and even in jawed fishes (Medina et al., 2005). This is important to search for evolutionary conserved sets of cells or for novel cell groups in equivalent prosomeres, as well as to look whether all prosomeres 
are present or not in the more basal agnathans (i.e. lampreys) and in non-vertebrate chordates (i.e. amphioxus).

\section{Homologous genes, non-homologous structures. The pat- terning of the limbs and the appendages}

In the heyday of 'functional homology', finding orthologous genes expressed in similar areas of limbs in vertebrates and appendages in arthropods led to think of these structures as homologous; that is, derived from an ancestor already bearing them (Panganiban et al., 1997). After the excitement, and because phylogenetically intermediate taxa do not possess comparable structures, common sense returned and limbs and appendages were seen as what they were for more than 100 years: analogous structures. The novelty was, however, that although they are analogous in morphological and embryological terms, they seem patterned by homologous genes (Tabin et al., 1999). Current explanations on how homologous genes control the development of non-homologous structures could be through: 1) independent recruitment of individual genes in arthropods and vertebrates; 2 ) sets of genes already linked together but used (coopted) for a different purpose; and 3) genes linked into a network that patterned some sort of outgrowth from the body wall of the PDA, not homologous to modern appendages in any group. Evidence gathered in the last 10 years, involving the work of a few spanish research groups, supports the last alternative.

Despite vertebrate limbs and arthropod appendages are clearly different, there is an striking parallelism in their Proximo-Distal (PD) patterning (reviewed in Pueyo and Couso, 2005, and Tabin and Wolpert, 2007). As first shown by Gonzalez-Crespo and Morata (1996), working at the CBM in Madrid, the leg primordium in Drosophila first subdivides into a proximal domain where the trunk homeobox genes extradenticle (exd) and homothorax (hth) are expressed and a distal domain that expresses the gene Distalless (DII). Further, they showed that hth-exd is first expressed all over the early leg primordium but is eliminated from the distal precursor cells by the activation of DII. When expressed ectopically in distal cells, exd prevents distal development and give rise to truncated legs. Reciprocal antagonism between hthexd and DII keeps the proximal and the distal domains separate, domains that correspond to the coxopodite and the telopodite proposed by Snodgrass (1935). Later, a medial domain is defined by the activation of the gene daschund (dac) (Lecuit and Cohen, 1997), and the three PD domains are maintained by mutual repression. Further subdivisions require the activation of further transcription factors (Galindo et al., 2002; Pueyo and Couso, 2005).

Following the steps of Drosophila leg PD patterning, the groups of Miguel Torres (Centro Nacional de Biotecnologia, CNB) and Ginés Morata (CBM) looked for the expression of homologues to hth, exd and DII in developing vertebrate limbs. Prior to the appearance of the limb bud, it was shown that the hth homologue Meis is expressed in the lateral plate (Mercader et al., 1999). As the limb bud starts growing, Meis expression is kept in the proximal domain but starts to disappear from the distal domain close to the Apical Ectodermal Ridge (AER) where Fibroblast Growth Factor genes (Fgfs) and DIx (the homologue of DII) are expressed. As in Drosophila, ectopic activation of Meis in the distal domain causes truncation or proximalisation of distal structures (Mercader et al., 2000). Moreover, Dach1, the vertebrate homologue of "dac, is expressed in a medial to distal domain and seems to be a repressor of Meis. In later stages, Hox gene expression appears so that Meis1 becomes a marker for the stylopod, Hoxa11 for the zeugopod and Hoxa13 for the autopod (reviewed in Tabin and Wolpert, 2007).

Later stages of vertebrate developing limb, namely formation of the digits in amniota embryos, were studied in the 1990s and early 2000ths by the group of Juan Hurlé (Universidad de Cantabria, Santander). They analyzed the role of different growth factors on chondrogenesis and on apoptotic cell death leading to different morphological types of feet. In particular, they studied fgf8, BMPs, msx and gremlin in embryos of chicken, duck and other"vertebrate embryos. BMPS do have a dual role: promoting chondrogenesis in the digital regions and apoptosis in the interdigital regions (reviewed in Montero and Hurlé 2007). These differences depend on local expression of different Bmp receptors. From the paddleshaped primitive autopod in all amniote embryos, BMP and msx genes sculpt the final shape of hands, feets and digits triggering apoptosis in the undifferentiated cells of the interdigital zone. In species bearing free digits (Gañán et al., 1998), BMP and msx trigger apoptosis; in those forming webbed feet (e.g. the duck, the tortoise), BMP and msx are similarly expressed but its apoptotic functions are antagonized by gremlin, highly expressed in the interdigital mesenchyme'(Merino et al., 1999). Indeed, duck-like syndactily is induced in the chick by application of exogenous Gremlin in the interdigital mesoderm.

In summary, the work of spanish groups has helped to uncover the striking conservation of a gene network operating at early stages to subdivide limbs and appendages into three PD parts (proximal, medial and distal). Moreover, other sets of genes: Shh/ hh and BMP/dpp for the A-P axis; Lmx-1/ap for the D-V axis, and others like Wnt3/wg driving distal outgrowth, are also called upon in both systems. Because there has been no continuity of any structure from which the insect and vertebrate appendages can be derived, this genetic network was very likely assembled to pattern any sort of ancestral outgrowths in early bilaterians or, even earlier on, in diploblastic cnidarians.

\section{Conclusions and prospects}

The history of Evolution and Development in Spain is a very short story with some brilliant spells and an uncertain future. The almost total lack of tradition in Embryology, Genetics and Evolution was an unbearable historical burden (Fig. 2A) only overcome by the intellectual stamina of people like Pere Alberch, working outside Spain, and Antonio García-Bellido who started Developmental Genetics in Spain from scratch (Fig. 2B). From this tepid beginning, the 1990s witnessed some brilliant Evo-Devo spells in a few scattered labs (Fig. 4). First, new molecular phylogenies relocalized some extant animal groups (i.e. acoelomorph flatworms and cephalochordates, among others) in key positions in the phylogenetic ladder, driving them to the forefront in the analyses of major morphological evolutionary transitions. Further, the finding of the common genetic toolkit in all animals, together with the spread of developmental genetics in several labs in Spain, arising from the Madrid school, produced a wealth of comparative expression data in Drosophila and other animal models to test how genes control morphologies and how changes in these genes may drive morphological evolution. 
As of today, Evo-Devo studies follow a dual approach. First, the 'macro-evolutionary' approach is asking how and when developmental genes were assembled, at key points in the phylogenetic ladder, into interacting functional networks to determine regional and tissue specific identities. Second, the 'micro-evolutionary' approach is analyzing how changes in the cis-regulatory and codifying regions of specific genes correlate with specific morphological changes and how their variants could spread in natural populations. Under both approaches, predictions drawn from actual comparative studies should be tested in experimental systems, namely using transgenic organisms (= functional EvoDevo).

Both macro- and micro-evolutionary approaches, and namely functional Evo-Devo, need well-financed research groups composed of embryologists, cell biologists, developmental geneticists, bioinformaticians and genetic engineers, working on privileged key Evo-Devo model systems. Such constellations of people do not occur nowadays, as far as I know, in any Spanish lab. As of today, too many biological labs in Spain are driven by the so-called applied or social-oriented science into the safe, but conceptually less enticing, realms of Biomedicine and Biotechnology. Even so, it is to be hoped that Spanish Evo-Devo researchers will promote the development of such multidisciplinary groups and inspire a new generation of developmental biologists into this passionate field.

\section{Acknowledgements}

To those whose work I could not cite and comment due to space constraints and memory limitations, my sincere apologies. I am very grateful to Jordi Garcia-Fernàndez for useful tips on Evo-Devo subjects and people, and to all reviewers for their insightful comments and constructive criticisms. All comments written down here represent my own personal views and thoughts for which I am completely responsible.

\section{References}

ABOUHEIF, E. (1997). Developmental genetics and homology: a hierarchical approach. Trends in Ecology and Evolution. 12: 405-403.

ADOUTTE, A., BALAVOINE, G., LARTILLOT, N., LESPINET, O., PRUD'HOMME, B. and DE ROSA, R. (2000). The new animal phylogeny: reliability and implications. Proc. Natl. Acad. Sci. USA. 97: 4453-4456.

AGUINALDO, A.M.A., TURBEVILLE, J.M., LINDFORD, L.S., RIVERA, M.C., GAREY, J.R., RAFF, R.A. and LAKE, J.A. (1997). Evidence for a clade of nematodes, arthropods and other moulting animals. Nature. 387: 489-493.

ALBERCH, P. (1982). Developmental constraints in evolutionary processes. In: Evolution and Development. Dahlem Conference Report No 20. (J.T. Bonner, Ed), pp 313-332. Springer-Verlag, Berlin.

ALBERCH, P., GOULD, S.J., OSTER, G. and WAKE, D.B. (1979). Size and shape in ontogeny and phylogeny. Paleobiology. 5(3): 296-317.

BAGUÑ̀̀, J. and GARCÍA-FERNÀNDEZ, J. (2003). Evolution and Development. Special Issue. Int. J. Dev. Biol. 47(7/8): 469-727.

BAGUÑ̀̀, J. and RIUTORT, M. (2004a). The dawn of bilaterian animals: the case of the acoelomorph flatworms. BioEssays. 26: 1046-1057.

BAGUÑ̀̀, J. and RIUTORT, M. (2004b). Molecular phylogeny of the Platyhelminthes. Can. J. Zool. 82: 168-193.

BAGUÑ̀̀, J., MARTINEZ, P., PAPS, J. and RIUTORT, M. (2008a). Unravelling body-plan and axial evolution in the Bilateria with molecular phylogenetic markers. In Evolving Pathways: Key Themes in Evolutionary Developmental Biology (A. Minelli and G. Fusco, Eds), pp. 217-238. Cambridge University Press, Cambridge, UK

BAGUÑÀ, J., MARTÍNEZ, P., PAPS, J. and RIUTORT, M. (2008b). Back in time: a new systematic proposal for the Bilateria. Phil. Trans. R. Soc. $B$ (363: 1481-
1491; doi: 10.1098/rstb.2007.2238).

BARRALLO-GIMENO, A. and NIETO, M.A. (2006). Evolution of the neural crest. Adv. Exp. Med. Biol. 589: 235-244.

BONNER, J.T. (1982). Evolution and Development. Dahlem Conference Report No 20. Springer-Verlag, Berlin. Pp 357.

BOURLAT, S.J., JULIUSDOTTIR, T., LOWE, C.J., FREEMAN, R., ARONOWICZ, J., KIRSCHNER, M., LANDER, E.S., THORNDYKE, M., NAKANO, H., KOHN A.B., HEYLAND, A., MOROZ, L., COPLEY, R.R. and TELFORD, M.J. (2006). Deuterostome phylogeny reveals monophyletic chordates and the new phylum Xenoturbellida. Nature. 444: 85-88.

BROOKE, N.M., GARCÍA-FERNÀNDEZ, J. and HOLLAND, P.W.H. (1998). The ParaHox gene cluster is an evolutionary sister of the Hox gene cluster. Nature. 392: 920-922

BUDD, G.E. (1999). Does evolution in body patterning genes drive morphological change - or vice versa? BioEssays. 21: 326-332.

BUDD, G.E. (2006). On the origin and evolution of the major morphological characters. Biol. Rev. 81(4): 609-628

CAMPUZANO, S. and MODOLELL, J. (1992). Patterning of the Drosophila nervous system: the Achaete-Scute complex. Trends in Genetics. 8: 202-208.

CANO, A., PEREZ-MORENO, M.A., RODRIGO, I., LOCASCIO, A., BLANCO, M.J., DEL BARRIO, M.G., PORTILLO, F. and NIETO, M.A. (2000). The transcription factor Snail, controls epithelial-mesenchymal transitions by repressing $\mathrm{E}$ cadherin expression. Nature Cell Biol. 2: 76-83.

CARRANZA, S., BAGUÑÀ, J. and RIUTORT, M. (1997). Are the Platyhelminthes a monophyletic primitive group? An assessment using 18S rDNA sequences. Mol. Biol. Evol. 14: 485-497.

CARROLL, S.B., GRENIER, J.K. and WEATHERBEE, S.D. (2001). From DNA to Diversity. Molecular Genetics and the Evolution of Animal Design. Blackwell Science, Malden, MS, USA.

CASTELLI-GAIR, J. and LOVEGROVE, B. (2003). Beyond homeosis - HOX function in morphogenesis and organogenesis. Differentiation. 71: 461-476.

COOK, C.E., JIMENEZ, E., AKAM, M. and SALÓ, E. (2004). The Hox gene complement of acoel flatworms, a basal bilaterian clade. Evol. Dev. 6: 154-163.

DAVIDSON, E.H. and ERWIN, D.H. (2006). Gene regulatory networks and the evolution of animal body plans. Science. 311: 796-800.

DENES, A.S., JÉKELY, G., STEINMETZ, P.R.H., RAIBLE, F., SNYMAN, H., PRUD'HOMME, B., FERRIER, D.E.K., BALAVOINE, G. and ARENDT, D. (2007). Molecular architecture of annelid nerve cord supports common origin of nervous system centralization in Bilateria. Cell. 129: 277-288.

DOPAZO, H. and DOPAZO, J. (2005). Genome-scale evidence of the nematodearthropod clade. Genome Biology. 6: R41.

ELDREDGE, N. and GOULD, S.J. (1972). Punctuated equilibria: an alternative to phyletic gradualism. In: Models in Paleobiology (T.J.M. Schopf, Ed), pp 82-115. Freeman and Cooper, San Francisco.

FIELD, K.G., OLSEN, G.J., LANE, D.J., GIOVANNONI, S.J., GHISELIN, M.T., RAFF, E.C., PACE, N.R. and RAFF, R.A. (1988). Molecular phylogeny of the animal kingdom. Science. 239: 748-753.

FUTUYMA, D.J. (2002). Stephen Jay Gould à la recherche du temps perdu. Science. 296: 661-663.

GALINDO, M.I., BISHOP, S.A., GREIG, S. and COUSO, J.P. (2002). Leg patterning driven by proximal-distal interactions and EGFR signalling. Science. 297: 256259.

GALIS, F., VAN ALPHEN, J.J.M. and METZ, J.A.J. (2001). Why five fingers? Evolutionary constraints in digit number. Trends in Ecology \& Evolution. 16(11): 637-646.

GAÑÁN, Y., MACIAS, D., BASCO, R.D., MERINO, R. and HURLÉ, J.M. (1998) Morphological diversity of the avian foot is related with the pattern of msx gene expression in the developing autopod. Dev. Biol. 196: 33-41.

GARCÍA-BELLIDO, A. (1975). Genetic control of wing development in Drosophila. In: Cell Patterning. Ciba Symposium, Vol 29, pp 161-182. Elsevier, Amsterdam.

GARCíA-BELLIDO, A. (1977). Homeotic and atavic mutations in insects. Amer. Zool. 17: 613-629.

GARCÍA-BELLIDO, A. (1983). Comparative anatomy of cuticular patterns in the genus Drosophila. In: Development and Evolution. (B.C. Goodwin., N. Holder 
and C.C. Wylie, Eds.), pp 227-255. Cambridge University Press, Cambridge.

GARCÍA-BELLIDO, A. and DE CELIS, J.F. (1992). Developmental genetics of the venation pattern of Drosophila. Annu. Rev. Gen. 26: 275-302.

GARCÍA-BELLIDO, A., RIPOLL, P. and MORATA, G. (1973). Developmental compartmentalization of the wing disk of Drosophila. Nature New Biol. 245: 251 253.

GARCÍA-FERNÀNDEZ, J. (2005). The genesis and evolution of homeobox gene clusters. Nature Rev. Genet. 6: 881-892.

GARCÍA-FERNÀNDEZ, J. and HOLLAND, P.W.H. (1994). Archetypal organization of the amphioxus Hox gene cluster. Nature. 370: 563-566.

GILBERT, S.F. (2003). The morphogenesis of evolutionary developmental biology. Int. J. Dev. Biol. 47: 467-477.

GIRIBET, G. and RIBERA, C. (2000). A review of Arthropod phylogeny: new data based on ribosomal DNA sequences and direct character optimization. Cladistics. 16: 204-231.

GIRIBET, G., DISTEL, D.L., POLZ, M., STERRER, W. and WHEELER, W.C. (2000). Triploblastic relationships with emphasis on acoelomates and the position of Gnathostomulida, Cycliophora, Plathelminthes and Chaetognatha: a combined approach of $18 \mathrm{~S}$ rDNA sequences and morphology. Syst. Biol. 49: 539-562.

GIRIBET, G., EDGECOMBE, G.D. and WHEELER, W.C. (2001). Arthropod phylogeny based on eight molecular loci and morphology. Nature. 413: 157-161.

GOULD, S.J. (1977). Ontogeny and Phylogeny. Harvard University Press, Cambridge

GONZALEZ-CRESPO, S. and MORATA, G. (1996). Genetic evidence for the subdivision of the arthropod limb into coxopodite and telopodite. Development. 122: 3921-3928.

HEJNOL, A. and MARTINDALE, M.Q. (2008). Acoel development supports a simple planula-like urbilaterian. Phil. Trans. R. Soc. B. (363: 1493-1501; doi:10.1098/rstb.2007.2239)

HOLLAND, P.W.H., GARCÍA-FERNÀNDEZ, J., WILLIAMS, N.A. and SIDOW, A. (1994). Gene duplications and the origins of vertebrate development. Development. Suppl: 125-133.

JACOB, F. (1977). Evolution and tinkering. Science. 196: 1161-1166.

JIMÉNEZ-GURI, E., PAPS, J., GARCÍA-FERNÀNDEZ, J. and SALÓ, E. (2006). Hox and ParaHox genes in Nemertodermatida, a basal bilaterian clade. Int. J. Dev. Biol. 50: 675-679.

JONDELIUS, U., RUIZ-TRILLO, I., BAGUÑ̀̀, J. and RIUTORT, M. (2002). The Nemertodermatida are basal bilaterians and not members of the Platyhelminthes. Zool. Scr. 31: 201-215.

LECUIT, T., and COHEN, S.M. (1997). Proximo-distal axis formation in the Drosophila leg. Nature. 388: 139-145.

LEWIS, E.D. (1978). A gene complex controlling segmentation in Drosophila. Nature. 276: 565-570.

LOCASCIO, A., MANZANARES, M., BLANCO, M.J. and NIETO, M.A. (2002) Modularity and reshuffling of Snail and Slug expression during vertebrate evolution. Proc. Natl. Acad. Sci. USA. 99: 16841-16846.

LOWE, C.J., WU, M., SALIC, A., EVANS, L., LANDER, E., STANGE-THOMANN, N., GRUBER, C.E., GERHART, J. and KIRSCHNER, M. (2003). Anteroposterior patterning in Hemichordates and the origins of the chordate Nervous System. Cell. 113: 853-865.

MANZANARES, M., WADA, H., ITASAKI, N., TRAINOR, P.A., KRUMLAUF, R. and HOLLAND, P.W.H. (2000). Conservation and elaboration of Hox gene regulation during evolution of the vertebrate head. Nature. 408: 854-857.

MARTINDALE, M.Q. (2005). The evolution of metazoan axial properties. Nature. Rev. Genet. 6: 917-929.

MARTINDALE, M.Q., PANG, K. and FINNERTY, J.R. (2004). Investigating the origins of triploblasty: 'mesodermal' gene expression in a diploblastic animal, the sea anemone Nematostella vectensis (phylum, Cnidaria; class, Anthozoa). Development. 131: 2463-2474.

MATUS, D.Q., THOMSEN, G.H. and MARTINDALE, M.Q. (2006). Dorso/Ventral genes are asymmetrically expressed and involved in germ-layer demarcation during cnidarian gastrulation. Current Biology. 16: 499-505.

MATUS, D.Q., PANG, K., DALY, M. and MARTINDALE, M.Q. (2007). Expression of Pax gene family members in the anthozoan cnidarian, Nematostella vectensis. Evol. Dev. 9: 25-38.

MAXAM, A. and GILBERT, W. (1977). A new method for sequencing DNA. Proc Natl. Acad. Sci., USA. 74: 560-564.

McGINNIS, W., LEVINE, M.S., HAFEN, E., KUROIWA, A. and GEHRING, W.J. (1984a). A conserved DNA-sequence in homeotic genes of the Drosophila Antennapedia and Bithorax complexes. Nature 308: 428-433.

McGINNIS, W., GARBER, R.L., WIRZ, J., KUROIWA, A. and GEHRING, W.J. (1984b). A homologous protein-coding sequence in Drosophila homeotic genes and its conservation in other metazoans. Cell. 37: 403-408.

MEDINA, L., BROX, A., LEGAZ, I., GARCÍA-LÓPEZ, M. and PUELLES, L. (2005) Expression patterns of developmental regulatory genes show comparable subdivisions in the telencephalon of Xenopus and mouse: insights into the evolution of the forebrain. Brain. Res. Bull. 66: 297-302.

MERCADER, N., LEONARDO, E., AZPIAZU, N., SERRANO, A., MORATA, G. MARTINEZ-A, C. and TORRES, M. (1999). Conserved regulation of proximodista limb axis development by Meis 1/Hth. Nature. 402: 425-429.

MERCADER, N., LEONARDO, E., PIEDRA, M.E., MARTíNEZ-A, C., ROS, M.A and TORRES, M. (2000). Opposing RA and FGF signals control proximodistal vertebrate limb development through regulation of Meis genes. Development. 127: $3961-3970$

MEYER, A. and ZARDOYA, R. (2003). Recent advances in the (molecular) phylogeny of Vertebrates. Annu. Rev. Ecol. Syst. 34: 311-338.

MERINO, R., RODRIGUEZ-LEON, J., MACIAS, D., GAÑÁN, Y., ECONOMIDES A.N. and HURLÉ, J.M. (1999). The BMP antagonist Gremlin regulates outgrowth, chondrogenesis and programmed cell death in the developing limb. Development 126: 5515-5522.

MONTERO, J.A. and HURLÉ, J.M. (2007). Deconstructing digit chondrogenesis BioEssays 29: 725-737.

NÜSSLEIN-VOLHARD, C. and WIESCHAUS, E. (1980). Segmentation in Drosophila: mutations affecting segment number and polarity. Nature. 287: 795-801.

ODELL, G., OSTER, G., ALBERCH, P. and BURNSIDE, B. (1981). The mechanical basis of morphogenesis. I: a model for epithelial tissue folding. Devel. Biol. 85 : 446-462.

OHNO, S. (1970). Evolution by Gene Duplication. Springer-Verlag, New York, NY. 160pp.

OSTER, G. and ALBERCH, P. (1982). Evolution and bifurcation of developmental programs. Evolution. 36(3): 444-459.

PANGANIBAN, G., IRVINE, S.M., LOWE, C., ROEHL, H., CORLEY, S., SHERBON, B., GRENIER, J.K., FALLON, J.F., KIMBLE, J., WALKER, M., WRAY, G.A., SWALLA, B.J., MARTINDALE, M.Q. and CARROLL, S.B. (1997). The origin and evolution of animal appendages. Proc. Natl. Acad. Sci. USA. 94: 5162 5166.

PELAYO, F. (2002). Darwinismo y antidarwinismo en España (1900-1939): La extensión y crítica de las ideas evolucionistas. In: Evolucionismo y Cultura. Darwinismo en Europa e Iberoamérica (M.A. Puig-Samper., R. Ruiz. and A Galera, Eds), pp 267-284. Doce Calles.

PHILIPPE, H., BRINKMANN, H., MARTÍNEZ, P., RIUTORT, M. and BAGUÑÀ, J (2007). Acoel flatworms are not Platyhelminthes: evidence from phylogenomics. PLOS ONE2: e717.

PRUD'HOMME, B., GOMPEL, N., ROKAS, A., KASSNER, V.A., WILLIAMS, T.M. YEH, S.-D., TRUE, J.R. and CARROLL, S.B. (2006). Repeated morphological evolution through cis-regulatory changes in a pleiotropic gene. Nature. 440 1050- 1053.

PRUD'HOMME, B., GOMPEL, N. and CARROLL, S.B. (2007). Emerging principles of regulatory evolution. Proc. Natl. Acad. Sci. USA. 104: 8605-8612.

PUELLES, L. and RUBENSTEIN, J.L.R. (1993). Expression patterns of homeobox and oither putative regulatory genes in the embryonic mouse forebrain suggest a neuromeric organization. Trends. Neurosci. 16: 472-479.

PUELLES, L. and RUBENSTEIN, J.L.R. (2003). Forebrain gene expression do mains and the evolving prosomeric model. Trends. Neurosci. 26: 469-476.

PUEYO, J.I. and COUSO, J.P. (2005). Parallels between the proximal-distal development of vertebrate and arthropod appendages: homology without an ancestor?. Curr. Opin. Genet \& Dev. 15: 1-8.

RAFF, R.R. (2000). Evo-devo: the evolution of a new discipline. Nature Rev. Genet. 
1: 74-79.

RUIZ-TRILLO, I., RIUTORT, M., LITTLEWOOD, D. T. J., HERNIOU, E. A. and BAGUÑÀ, J. (1999). Acoel flatworms: earliest extant Bilaterian Metazoans, not members of Platyhelminthes. Science. 283: 1919-1923.

RUIZ-TRILLO, I., PAPS, J., LOUKOTA, M., RIBERA, C., JONDELIUS, U., BAGUÑ̀̀, J \& RIUTORT, M. (2002). A phylogenetic analysis of myosin heavy chain type II sequences corroborates that Acoela and Nemertodermatida are basal bilaterians. Proc. Natl. Acad. Sci. USA 99: 11246-11251.

RYAN, J. F., MAZZA, M. E., PANG, K., MATUS, D. Q., BAXEVANIS, A. D., MARTINDALE, M. Q. and FINNERTY, J. R. (2007). Pre-Bilaterian origins of the Hox cluster and the Hox code: Evidence from the sea anemone, Nematostella vectensis. PLOS ONE2: e153.

SAKARYA, O., ARMSTRONG, K.A., ADAMSKA, M., WANG, I-FAN., TIDOR, B., DEGNAN, B.M., OAKLEY, T.H. and KOSIK, K.S. (2007). A post-synaptic scaffold at the origin of the Animal Kingdom. PLOS ONE. 6: e506.

SALVINI-PLAWEN, L. V. (1978). On the origin and evolution of the lower Metazoa. Z. Zool. Syst. Evol. 16: 40-88.

SANCHEZ-HERRERO, E., VERNOS, I., MARCO, R. and MORATA, G. (1985). Genetic organization of the Drosophila Bithorax complex. Nature 313: 108-113.

SAUKA-SPENGLER, T. and BRONNER-FRASER, M. (2006). Development and evolution of the migratory neural crest: a gene regulatory perspective. Curr. Opin. Genet \& Dev. 16: 360-366.

SEMPERE, L., COLE, C. N., MCPEEK, M. A. and PETERSON, K. J. (2006). The phylogenetic distribution of Metazoan microRNAs: insights into evolutionary complexity and constraint. J. Exp. Zool. (Mol. Dev. Evol). 306B: 575-588.

SEMPERE, L.F., MARTÍNEZ, P., COLE, C., BAGUÑÀ, J. and PETERSON, K. J. (2007). Phylogenetic distribution of microRNAs supports the basal position of acoel flatworms and the polyphyly of Platyhelminthes. Evol. Deve/9, 409-415.

SHUBIN, N.H. and ALBERCH, P. (1986). A morphogenetic approach to the origin and basic organization of the tetrapod limb. In: Evolutionary Biology, Vol 20 (M.A Hecht,, B. Wallace. and G.T. Prance, Eds), pp 319-386. Plenum Press, New York and London.

SHUBIN, N.H, TABIN, C. and CARROLL, S.B. (1997). Fossils, genes and the evolution of animal limbs. Nature. 388: 639-648.

SIMPSON, P. (2007). The stars and stripes of animal bodies: evolution of regulatory elements mediating pigment and bristle patterns in Drosophila. Trends in Genetics. 23: 350-358.

SNODGRASS, R.E. (1935). Principles of Insect Morphology. McGraw-Hill, New York.

TABIN, C. and WOLPERT, L. (2007). Rethinking the proximodistal axis of the vertebrate limb in the molecular era. Genes. Dev. 21: 1433-1442.

TABIN, C., CARROLL, S.B. and PANGANIBAN, G. (1999). Out on a limb: parallels in vertebrate and invertebrate limb patterning and the origin of appendages. Amer. Zool. 39: 650-663.

VALENTINE, J.W. (2004). On the Origin of Phyla. University of Chicago Press, Chicago, IL.

WALLBERG, A., CURINI-GALLETTI, M., AHMADZADEH, A. \& JONDELIUS, U. (2007). Dismissal of Acoelomorpha: Acoela and Nemertodermatida are separate early bilaterian clades. Zool. Scr. 36: 509-523.

WILLMER, P. (1990). Invertebrate Relationships. Patterns in Animal Evolution. Cambridge University Press, Cambridge, UK.

WOESE, C.R., MAGRUM, L.J. and FOX, G.E. (1978). Archaebacteria. J. Mol. Evol. 11: $245-251$

\section{Related, previously published Int. J. Dev. Biol. articles}

See our recent Special Issue Developmental Biology in Poland edited by Tarkowski, Maleszewski and Kloc at:

http://www.ijdb.ehu.es/web/contents.php?vol=52\&issue=2-3

See our recent Special Issue Ear Development edited by Fernando Giraldez and Bernd Fritzsch at:

http://www.ijdb.ehu.es/web/contents.php?vol=51\&issue=6-7

Putting Evo-Devo into focus. An interview with Scott F. Gilbert Alexander T. Mikhailov

Int. J. Dev. Biol. (2005) 49: 9-16

Evo-Devo: the long and winding road.

Jaume Baguñà and Jordi Garcia-Fernàndez

Int. J. Dev. Biol. (2003) 47: 705-713

Evo-Devo: evolutionary developmental mechanisms.

Brian K Hall

Int. J. Dev. Biol. (2003) 47: 491-495

The place of phylogeny and cladistics in Evo-Devo research.

Maximilian J Telford and Graham E Budd

Int. J. Dev. Biol. (2003) 47: 479-490

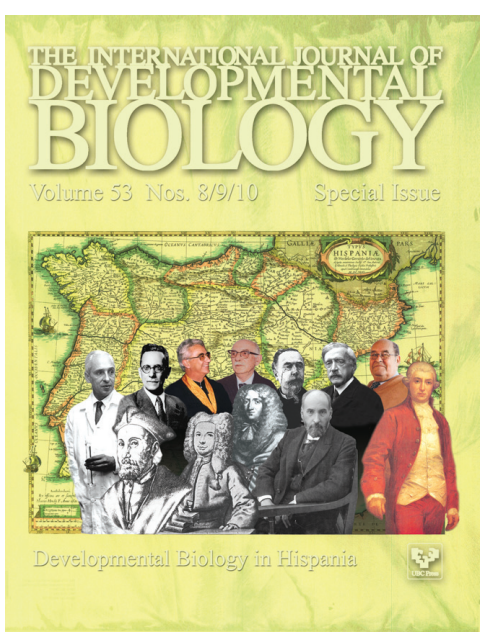

5 yr ISI Impact Factor $(2008)=3.271$

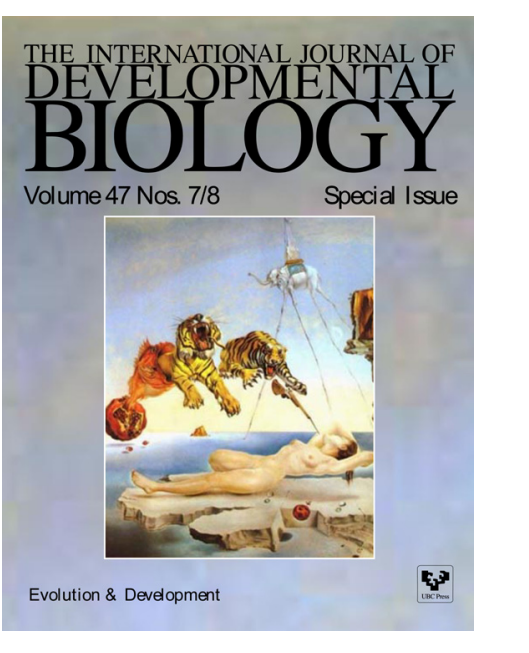

